\title{
Ocena struktury i wybranych właściwości złączy stopu aluminium i tytanu lutospawanych metodą CMT
}

\author{
Evaluation of the structure and selected properties of aluminum \\ alloy and titanium joints welded with the CMT method
}

\section{Streszczenie}

W artykule przedstawiono problematykę związaną z lutospawaniem łukowym elektrodą topliwą w osłonie gazów blach ze stopu aluminium 5754 z tytanem Grade 2. Omówiono możliwości wytwarzania tego rodzaju połączeń przy użyciu innowacyjnych niskoenergetycznych metod spawalniczych. Przedstawiono wyniki badań metalograficznych oraz mechanicznych (statycznej próby ścinania, pomiarów mikrotwardości) złączy lutospawanych wykonanych półautomatyczną metodą CMT (ang. Cold Metal Transfer).

Słowa kluczowe: lutospawanie łukowe; stopy aluminium; metoda CMT; tytan Grade 2

\begin{abstract}
The article presents the problems related to arc weldingbrazing hot-melt electrode in the gas shield of 5754 aluminum alloy sheets with titanium Grade 2. The possibilities of making such joints using innovative low-energy welding methods have been indicated. The results of metallographic and mechanical tests (static shear test, microhardness measurements) of weld brazed joints made by the semiautomatic CMT (Cold Metal Transfer) method have been presented.
\end{abstract}

Keywords: arc welding-brazing; aluminum alloys; CMT method; titanium Grade 2

\section{Wstęp}

Stale rosnące zapotrzebowanie na wytwarzanie konstrukcji, w których stosuje się materiały znacznie różniące się między sobą właściwościami mechanicznymi i fizykochemicznymi sprawia, że należy szukać coraz to bardziej innowacyjnych technologii ich łączenia. Wykonanie takich połączeń przy użyciu tradycyjnych technologii spajania jest często niemożliwe lub bardzo utrudnione pod względem technologiczno-metalurgicznym. Jest to natomiast uzasadnione i podyktowane korzystnymi właściwościami eksploatacyjnymi. Istotne są również względy ekonomiczne, ponieważ takie rozwiązania umożliwiają oszczędność kosztownych metali, do których należy tytan i jego stopy. Wpływa to jednocześnie na zmniejszenie kosztów całej konstrukcji, a w przypadku łączenia go ze stopami aluminium niewątpliwą korzyścią jest znaczna redukcja masy $[1 \div 3]$. Połączenia stopów aluminium z tytanem stosowane są w urządzeniach, w których wymagane jest połączenie właściwości lekkiego aluminium z bardzo wytrzymałym tytanem, a główny obszar ich zastosowań stanowi przemysł lotniczy, astronautyczny, motoryzacyjny i chemiczny $[1,2]$. Zwłaszcza w trzech pierwszych, oprócz wymiernych korzyści ekonomicznych, dużą rolę odgrywa zmniejszenie masy znajdujące bezpośrednie odzwierciedlenie w zwiększeniu osiągów oraz zmniejszeniu zużycia paliwa i emisji spalin.
Ponadto połączenia charakteryzują się dużą odpornością na korozję [3].

Łączenie tytanu ze stopami aluminium jest szczególnie utrudnione przy zastosowaniu konwencjonalnych metod spajania (np. spawania łukowego) ze względów metalurgicznych, ponieważ w procesach tych występuje stapianie i wymieszanie składników stopowych materiałów podstawowych i spoiwa, inicjujące tworzenie się kruchych faz międzymetalicznych niekorzystnie wpływających na właściwości mechaniczne połączeń [1 $\div 3]$. Ponadto obydwa metale łatwo wchodzą w reakcję ze składnikami powietrza, co również wpływa na jakość połączeń i wymaga zastosowania specjalnych metod spajania. Najczęściej do ich spajania stosuje się technologie spawania laserowego, wiązką elektronów, zgrzewania dyfuzyjnego i tarciowego (FSW) oraz lutowania dyfuzyjnego $[1,4,5]$. Opracowanie tzw. niskoenergetycznych procesów spawania i lutospawania łukowego elektrodą topliwą w osłonie gazów m.in. CMT (ang. Cold Metal Transfer), ColdArc, STT (ang. Surface Tension Transfer), CBT (ang. Controlled Bridge Transfer) spowodowało wzrost zainteresowania ze strony przemysłu nad możliwością ich zastosowania do wytwarzania tego typu połączeń. Dzięki zaawansowanym systemom sterowania parametrami napięcia łuku i natężenia prądu oraz specjalnym liniom synergicznym

Dr inż. Tomasz Wojdat, dr inż. Artur Lange, dr inż. Paweł Kustroń, inż. Dagmara Lądyszkowska, inż. Alicja Margielewska, inż. Sylwia Łamasz, inż. Aleksandra Jakubczyk - Politechnika Wrocławska.

Autor korespondencyjny/Corresponding author: tomasz.wojdat@pwr.edu.pl 
dedykowanym do lutospawania możliwe jest ograniczenie do minimum ilość ciepła wprowadzonego do złącza oraz niemalże całkowite wyeliminowanie odprysków [6]. Umożliwia to wyjście naprzeciw oczekiwaniom rynku i sprostanie stale rosnącym wymaganiom dotyczących estetyki wykonania i jakości wytwarzanych połączeń. Obecnie są to procesy powszechnie stosowane do łączenia cienkich blach stalowych z powłokami ochronnymi (cynkowymi lub aluminiowymi) w konfiguracjach jedno- lub różnoimiennych, najczęściej

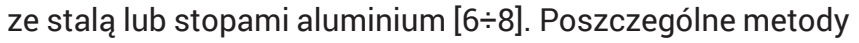
odróżnia sposób ingerencji w przebieg natężenia prądu i napięcia łuku podczas spawania łukiem zwarciowym [9].

Pomimo zaawansowanego systemu sterowania zastosowanego w ww. metodach, umożliwiającego dokładną kontrolę ilości wprowadzanego ciepła do złącza, proces lutospawania materiałów różnoimiennych nie odbywa się bez problemów. Największy problem związany jest z doborem spoiwa, którego wybór podyktowany jest temperaturą topnienia niżej topliwego materiału podstawowego, np. do wykonania połączeń lutospawanych aluminium ze stalą ocynkowaną używa się najczęściej spoiw siluminowych (Al-Si) [7,9]. Powoduje to, że często niemożliwe jest przeprowadzenie procesu lutospawania bez nadtopienia krawędzi niżej topliwego materiału, zwłaszcza w przypadku małego gradientu pomiędzy temperaturą jego topnienia i temperaturą topnienia spoiwa. Utrudnia to ocenę jakości takich połączeń, ponieważ nadtopienie materiału podstawowego w procesie lutospawania należy traktować jako niezgodność spawalniczą - dotyczy to zwłaszcza układu takich samych materiałów, natomiast w przypadku materiałów znacznie różniących się temperaturą topnienia, nadtopienie materiału niżej topliwego jest dopuszczalne. Ponadto mogą wystąpić również problemy z uzyskaniem dobrej zwilżalności na drugim materiale podstawowym lub tworzenie się kruchych faz międzymetalicznych w wyniku zjawisk dyfuzyjnych.

Złącza lutospawane tytanu Grade 2 ze stopem aluminium 5754, poddane badaniom w eksperymentalnej części niniejszej publikacji, wykonano przy użyciu metody CMT. Stanowiąca niskoenergetyczną odmianę MIG/MAG, metoda CMT charakteryzuje się odmiennym sposobem oddzielania kropli stopionego metalu od drutu elektrodowego, który podawany jest nie tylko w kierunku jeziorka, ale również okresowo wycofywany przez wysokoobrotowy podajnik drutu zintegrowany z uchwytem spawalniczym, co jest wykorzystywane również do sterowania procesem [8]. Powoduje to, że przejście stopionej kropli metalu z końca drutu do jeziorka spawalniczego odbywa się przy minimalnej wartości prądu, a nie jak w konwencjonalnym procesie MIG/MAG, w którym w danym momencie prąd ma największą wartość. Przerwanie zwarcia odbywa się zatem bez przepływu prądu, a przejście kropli metalu do jeziorka spawalniczego inicjowane jest przez wsteczny ruch drutu i odbywa się w wyniku oddziaływania sił napięcia powierzchniowego oraz siły ciężkości. Przejście metalu odbywa się przy bardzo niskich wartościach natężenia prądu, co znacząco wpływa na zmniejszenie energii cieplnej wprowadzanej do złącza, minimalizując jednocześnie odkształcenia łączonych elementów [8,9]. Dodatkową korzyścią, wynikającą z przejścia metalu w wyniku oddziaływania sił napięcia powierzchniowego, jest niemal całkowite wyeliminowanie odprysków, których usuwanie jest procesem czasochłonnym, kosztownym i nie zawsze w pełni skutecznym [6].

\section{Materiały i metodyka badań}

Do badań przygotowano zakładkowe złącza lutospawane metodą CMT. Łączono ze sobą stop aluminium AW 5754 (wg PN-EN 573-3) z tytanem Grade 2 (wg ASTM B265-15) przy użyciu spoiwa AlSi5 (wg PN-EN ISO 18273), którego wybór podyktowany był rodzajem i temperaturą topnienia niżej topliwego materiału podstawowego (stopu aluminium 5754). Skład chemiczny materiałów podstawowych i spoiwa przedstawiono w tablicy I. Wykonano dwa rodzaje złączy różniące się sposobem ułożenia materiałów podstawowych względem siebie. W pierwszym przypadku stop aluminium ułożony był na tytanie, a w drugim odwrotnie - tytan został ułożony na stopie aluminium. Próbki o wymiarach 100 x $80 \mathrm{~mm}$ i grubości $2 \mathrm{~mm}$ układano na zakładkę o długości $15 \mathrm{~mm}$, a uchwyt spawalniczy skierowany był na dolną blachę tuż przy krawędzi zakładki (rys. 1).

W celu zapewnienia równomiernego posuwu uchwytu spawalniczego wzdłuż krawędzi łączonych materiałów zamocowano go na półautomatycznej przecinarce M12 Bee Most, w miejsce palnika do cięcia. Takie rozwiązanie
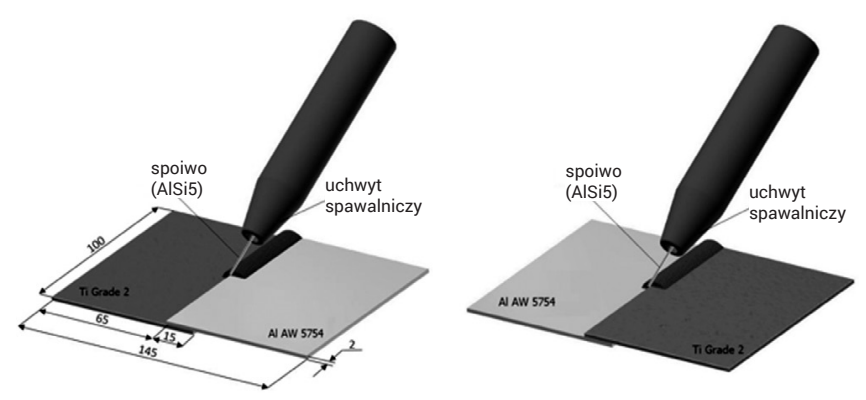

Rys. 1. Schemat wykonania lutospawanych złączy zakładkowych tytanu Grade 2 ze stopem aluminium 5754

Fig. 1. Schematic of execution of welding-brazing lap joints Grade 2 titanium with 5754 aluminum alloy

Tablica I. Skład chemiczny materiałów podstawowych i spoiwa [12 $\div 14]$

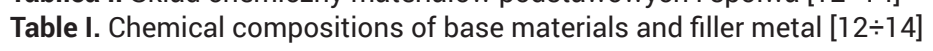

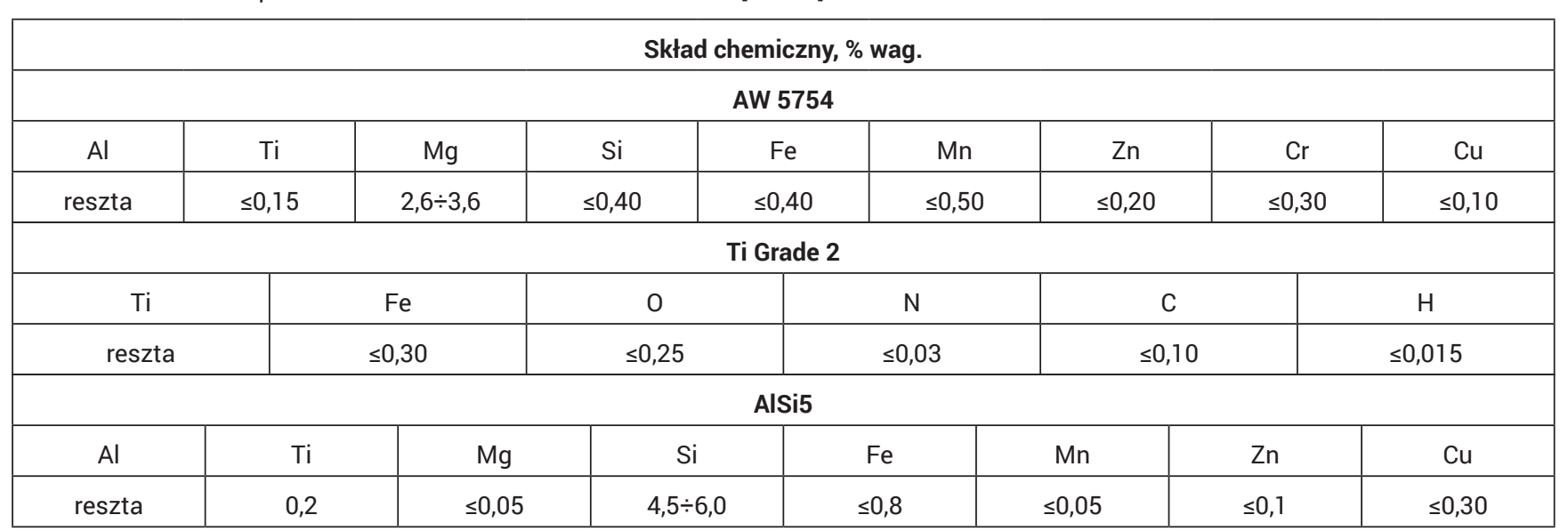


umożliwiło również regulację prędkości lutospawania w zakresie $0 \div 100 \mathrm{~cm} / \mathrm{min}$. Spawalnicze źródło prądu stanowiła sterowana mikrokomputerowo spawarka pulsacyjna TransPuls Synergic 3200 CMT zintegrowana ze sterowanym cyfrowo podajnikiem drutu VR 7000-CMT 4R/G/W/F++. Wstępne próby lutospawania wykazały, że proces lutospawania CMT wymaga bardzo precyzyjnego doboru parametrów technologicznych w bardzo wąskim zakresie, ponieważ nawet małe odstępstwo od tych określonych jako optymalne i wyznaczonych eksperymentalnie prowadziło do powstawania licznych niezgodności spawalniczych. Proces utrudniała również duża rzadkopłynność spoiwa AISi5 oraz nieduży gradient pomiędzy temperaturą jego topnienia i stopu aluminium 5754. Niewielkie zmiany parametrów powodowały m.in.: brak stabilności procesu i powstawanie odprysków, nadmierny nadlew lica, brak zwilżalności oraz przyklejenia. Złącza próbne wykonano dla następujących parametrów technologicznych: natężenie prądu $100 \mathrm{~A}$, napięcie łuku $11,7 \mathrm{~V}$, prędkość podawania drutu $6,0 \mathrm{~m} / \mathrm{min}$, prędkość lutospawania $45 \mathrm{~cm} / \mathrm{min}$, korekcja długości łuku -25. Jako gazu osłonowego użyto argonu o czystości 99,995\% (ARGON 4.5).

\section{Wyniki badań i dyskusja}

\section{Badania wizualne}

Wstępnej oceny jakości wykonanych złączy lutospawanych dokonano na podstawie badań wizualnych, które przeprowadzono zgodnie z wytycznymi normy PN-EN ISO 17637. Dobrano oświetlenie o natężeniu wynoszącym 500 Ix, które skierowane było na badane złącza pod kątem $45^{\circ}$, w celu zapewnienia odpowiedniego kontrastu. Obserwację prowadzono w odległości 450 $\div 500 \mathrm{~mm}$ od powierzchni przedmiotu, a kąt patrzenia wynosił $30^{\circ}$. Badania VT wykazały, że niezależnie od konfiguracji, złącza charakteryzują się estetycznym wyglądem. Można również zauważyć, że szerokość lica nie jest taka sama na całej długości złącza, tylko zwiększa się w kierunku zgodnym z kierunkiem lutospawania. Wynika to ze zmieniającej się $\mathrm{w}$ trakcie procesu pojemności cieplnej spawanych blach - nagrzewające się w trakcie procesu blachy sprzyjały lepszemu rozpływaniu się rzadkopłynnego stopiwa po ich powierzchni powodując zmiany szerokości lica lutospoiny (rys. 2).
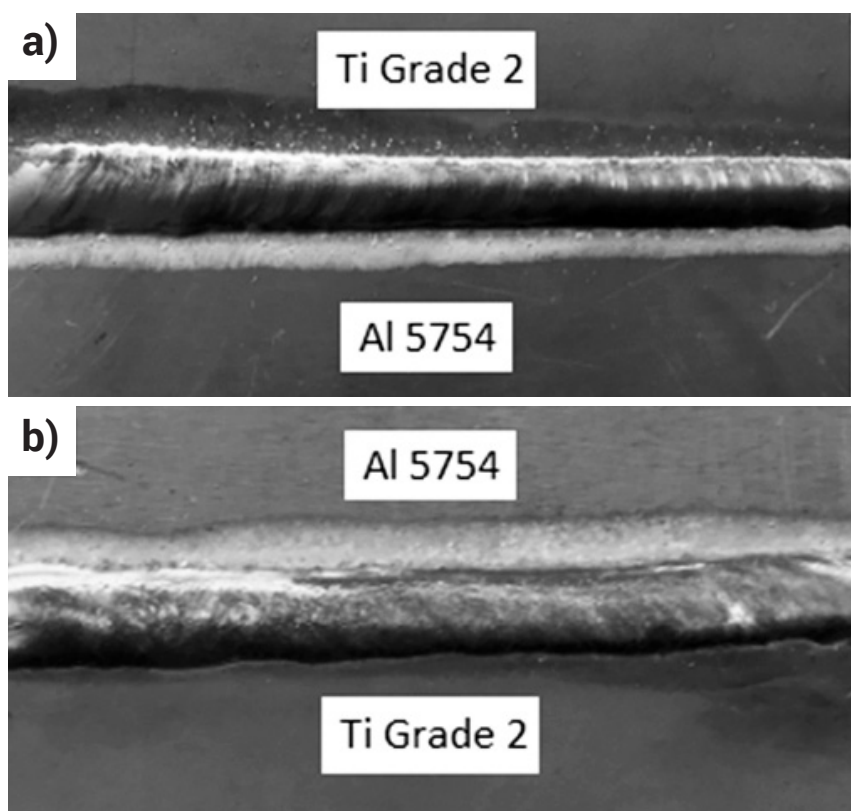

Rys. 2. Zakładkowe złącza lutospawane tytanu Grade 2 ze stopem aluminium 5754

Fig. 2. Lap weldbrazed joints Grade 2 titanium with 5754 aluminum alloy

\section{Badania metalograficzne}

Do badań metalograficznych posłużyły próbki wycięte ze środkowej części złączy lutospawanych, które zainkludowano w żywicy epoksydowej, a następnie szlifowano na wodnych papierach ściernych o gradacji od 180 do 2500 oraz polerowano zawiesiną $\mathrm{SiO}_{2}$ o wielkości ziaren ściernych 0,2 $\mu \mathrm{m}$, w celu uzyskania zgładów metalograficznych. Zgłady były trawione elektrolitycznie oraz $10 \%$ roztworem kwasu fluorowodorowego (HF). Badania makro- i mikroskopowe przeprowadzono zgodnie z normą PN-EN 12797:2002/A1:2005 przy użyciu mikroskopu stereoskopowego Olympus SZX7 (obserwacje makroskopowe) oraz mikroskopu świetlnego Olympus СК40M (obserwacje mikroskopowe).

W zależności od sposobu ułożenia materiałów podstawowych względem siebie przekrój poprzeczny utworzonych złączy różnił się znacznie od siebie. W konfiguracji, w której tytan Grade 2 ułożony był na stopie aluminium 5754 (rys. 3a) uzyskano wtopienie na całej grubości blachy aluminiowej, jednak bez wycieku stopiwa po drugiej stronie. Blacha tytanowa była zwilżona na całej powierzchni czołowej, bez widocznych nadtopień. Szerokość wtopienia od strony lutospoiny wynosiła $6 \mathrm{~mm}$, a przy dolnej krawędzi blachy $1,5 \mathrm{~mm}$. Wtopienie w blachę aluminiową spowodowane jest małym gradientem temperatury topnienia spoiwa i niżej topliwego materiału podstawowego oraz sposobem ustawienia uchwytu spawalniczego, ustawionego bliżej materiału tworzącego spód złącza, co powodowało koncentrację większej ilość ciepła na jego powierzchni. Zmiana konfiguracji złącza umożliwiła uzyskanie połączenia charakterystycznego dla procesu lutospawania. Ułożona na spodzie złącza blacha tytanowa Grade 2 zwilżana była stopiwem AISi5 na szerokości $6 \mathrm{~mm}$, bez widocznych śladów jej nadtopienia (rys. 3b). Stop aluminium 5754 również zwilżany był stopiwem wzdłuż krawędzi czołowej z widocznym, niedużym, nadtopieniem
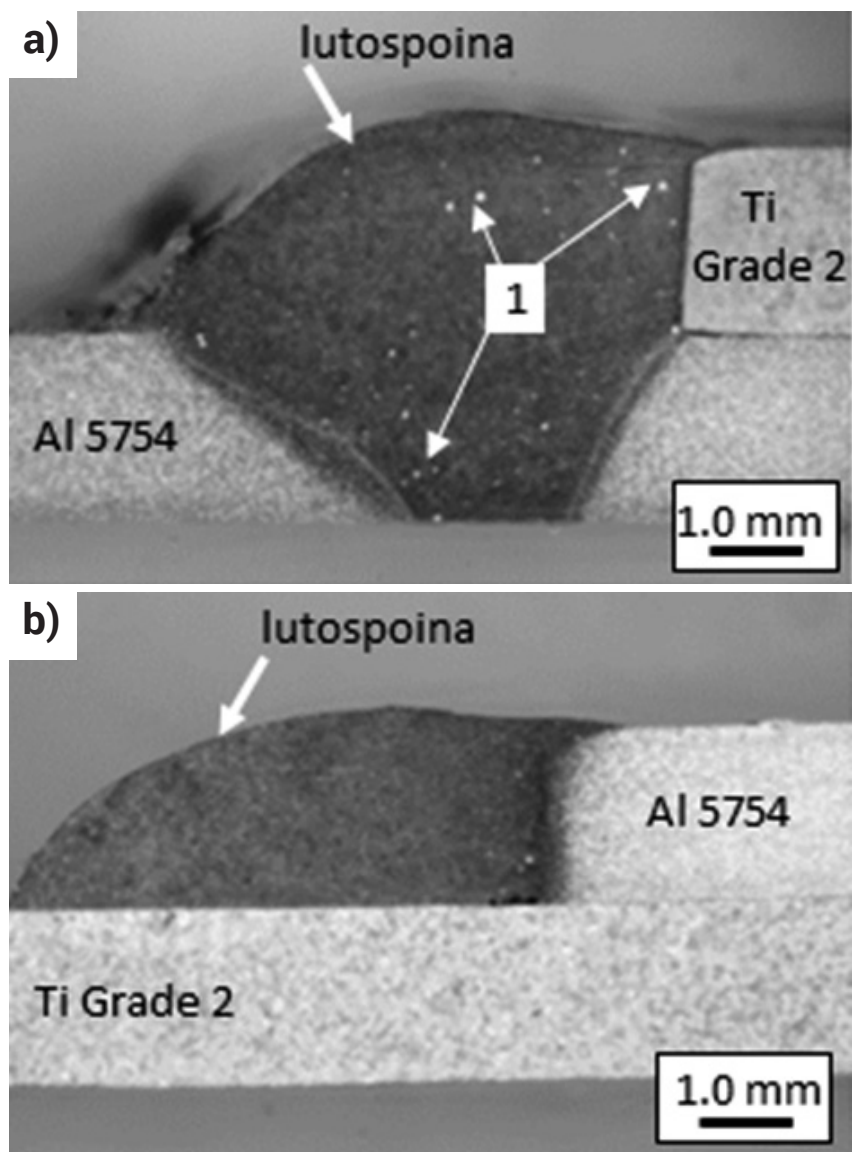

Rys. 3. Makrostruktura złączy lutospawanych tytanu Grade 2 ze stopem aluminium $5754 ; 1$ - pory gazowe

Fig. 3. Macrostructure of weldbrazed joints Grade 2 titanium with 5754 aluminum alloy; 1 - gas pores 
górnej jego krawędzi. W obydwu przypadkach nadlew lutospoiny nieznacznie wykraczał ponad krawędź blachy ułożonej na górze złącza zakładkowego.

Dla prawidłowej funkcjonalności złączy istotny jest brak nadtopienia tytanu Grade 2 i wymieszania jego składników ze stopiwem, w wyniku którego mogłoby dojść do utworzenia się kruchych faz międzymetalicznych typu $\mathrm{Si}_{3} \mathrm{Ti}_{5}$, TiAl i $\mathrm{TiAl}_{3}$, co zostało opisane w pracy [3]. Z uwagi na zbliżony skład chemiczny spoiwa i stopu aluminium 5754 wymieszanie ich składników nie powoduje tego rodzaju problemów.

Badania mikroskopowe również nie wykazały nadtopienia krawędzi tytanu Grade 2 oraz obecności faz międzymetalicznych w lutospoinie na granicy połączenia z tytanem (rys. 4a i 4b). Tytan Grade 2 jest dobrze zwilżany stopiwem na całej długości obejmującej strefę połączenia (2). Od strony topu aluminium 5754 widoczne jest wtopienie w materiał rodzimy z widoczną strefą przejściową (3) o szerokości w zakresie $70 \div 90 \mu \mathrm{m}$ (rys. 4c i 4d). Ponadto w lutospoinie występują śladowe ilości niezgodności postaci porów gazowych (1). Ich występowanie spowodowane jest dużym powinowactwem spoiwa siluminowego do tlenu.

\section{Pomiary mikrotwardości}

Pomiary mikrotwardości wykonano przy użyciu twardościomierza HVS-1000 firmy Sinowon metodą Vickersa przy obciążeniu 0,1 kG. Pomiary przeprowadzono w dwóch liniach pomiarowych (L1, L2) obejmujących strefę pomiędzy lutospoiną a tytanem Grade 2 (L1) oraz strefę pomiędzy lutospoiną a stopem aluminium 5754 (L2). Rozkład mikrotwardości w złączach zakładkowych pokazano na rysunku 5. a)

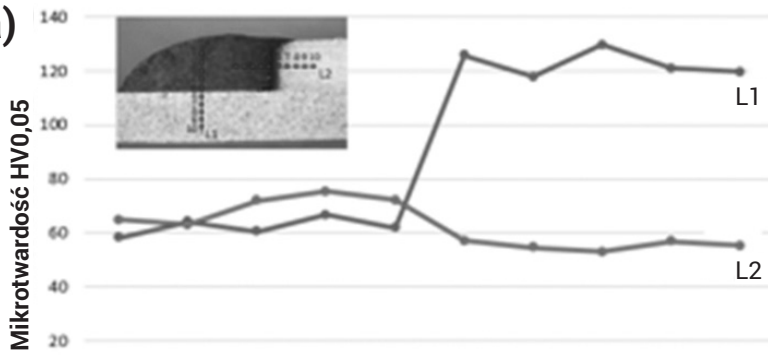

b)

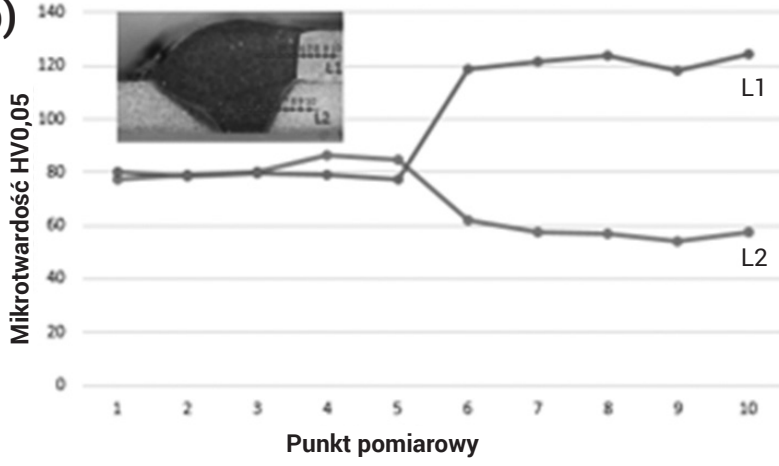

Rys. 5. Rozkład mikrotwardości w złączach lutospawanych w konfiguracji: a) tytan Grade 2 na dole złącza, b) stop aluminium 5754 na dole złącza

Fig. 5. The microhardness distribution in weldbrazed joints in the configuration: a) Grade 2 titanium at the bottom of the joint, b) aluminum 5754 alloy at the bottom of the joint
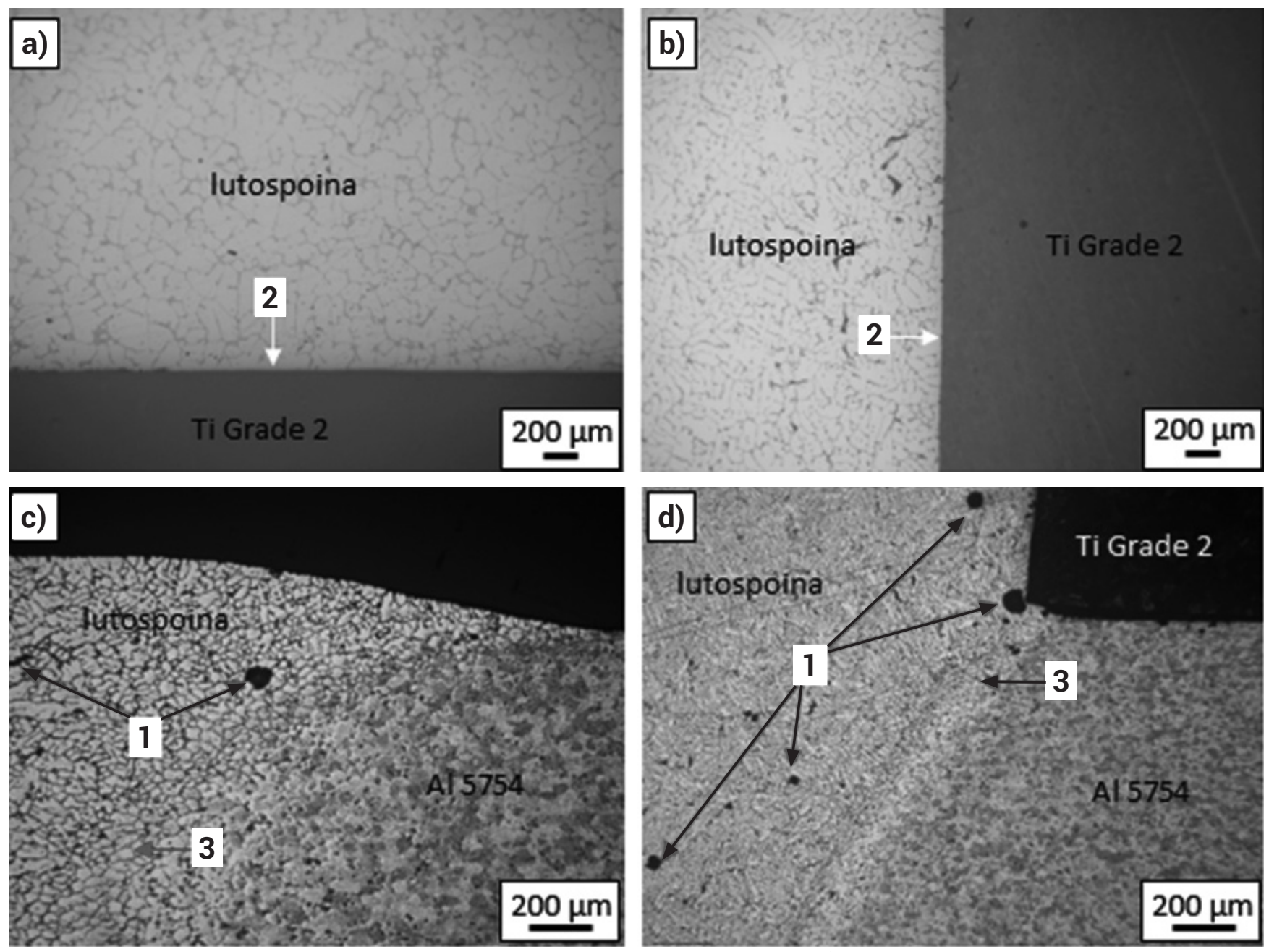

Rys. 4. Mikrostruktura złączy lutospawanych tytanu Grade 2 ze stopem aluminium 5754: a) strefa pomiędzy lutowiną a Ti, b) strefa pomiędzy lutowiną a Al.; 1 - pory gazowe, 2 - strefa zwilżenia, 3 - strefa przejściowa

Fig. 4. Microstructure of weldbrazed joints Grade 2 titanium with 5754 aluminum alloy: a) zone between braze and Ti, b) zone between braze and Al: 1 - gas pores, 2 - wettability zone, 3 - transition zone 
Rozkład twardości w materiałach rodzimych niezależnie od konfiguracji złącza był zbliżony, a średnia wartość wynosiła odpowiednio: 55,7 HV0,05 (rys. 5a) i 57,1 HV0,05 (rys. 5b) dla stopu aluminium 5754 oraz 124,1 HV0,05 (rys. 5a) i 121,3 HV0,05 (rys. 5b) dla tytanu Grade 2. Natomiast w lutospoinach można było zauważyć różnice w twardości występujące zarówno w strefie pomiędzy lutospoiną a tytanem (linia L1), gdzie średnia mikrotwardość wynosiła 63,7 HV0,05 (rys. 5a) i 78,9 HV0,05 (rys. 5b) oraz w strefie pomiędzy lutospoiną a aluminium (linia L2) - 70,1 HV0,05 (rys. 5a) i 84,4 HV0,05 (rys. 5b) z widocznym wzrostem twardości w strefie przejściowej. Większa o ok. 15 HV0,05 twardość w złączu wykonanym w układzie, w którym stop aluminium 5754 ułożony był na dole złącza, spowodowana jest najprawdopodobniej większym stopniem wymieszania stopiwa z materiałem rodzimym (aluminium).

\section{Statyczna próba ścinania}

Statyczną próbę ścinania poprzez rozciąganie zakładkowych złączy lutospawanych wykonano na uniwersalnej maszynie wytrzymałościowej Louis Schopper. Prędkość posuwu belki poprzecznej wynosiła $0,2 \mathrm{~cm} / \mathrm{min}$ a zakres pomiarowy do $10 \mathrm{kN}$. Próbki przygotowano zgodnie z PN-EN ISO 4136:2013, tak że szerokość w części pomiarowej wynosiła $12 \mathrm{~mm}$. Do badań wytrzymałościowych przygotowano po 3 próbki wycięte z każdego złącza.

Duży wpływ na wytrzymałość złączy lutospawanych miał sposób ułożenia materiałów podstawowych względem siebie. Ponad 3-krotnie większą wytrzymałość mechaniczną posiadały złącza, w których tytan Grade 2 ułożony był na dole, a średnia wytrzymałość wyniosła 184,8 MPa. Przełom następował w obszarze strefy wpływu ciepła w aluminium (rys. 7a). Złącza, w których tytan ułożony był na górze, gdzie zwilżana była tylko jego powierzchnia czołowa posiadały średnią wytrzymałość wynoszącą 51,3 MPa. Przełom następował w wyniku oderwania się lutospoiny od powierzchni czołowej blachy Ti (rys. 7b). Znaczne różnice w wytrzymałości spowodowane są dużą różnicą przekroju czynnego połączenia o charakterze dyfuzyjnym pomiędzy tytanem a lutospoiną.

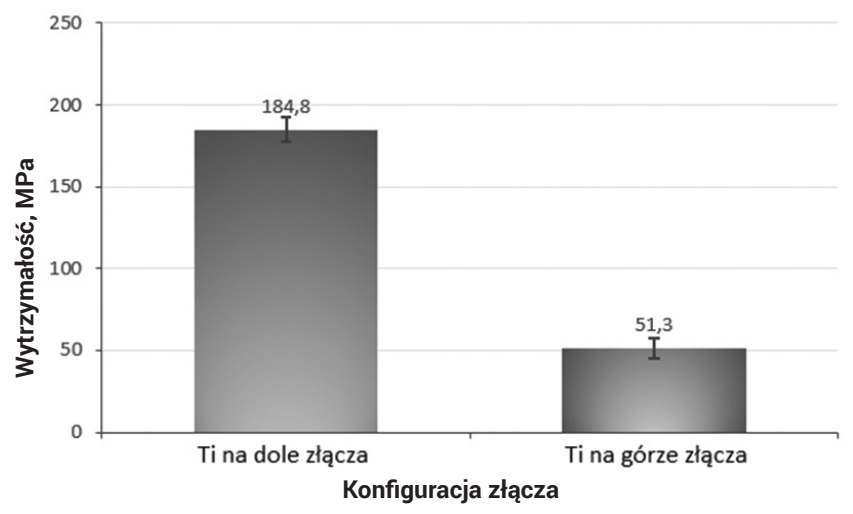

Rys. 6. Wytrzymałość mechaniczna złączy lutospawanych Fig. 6. Mechanical strength of weldbrazed joints
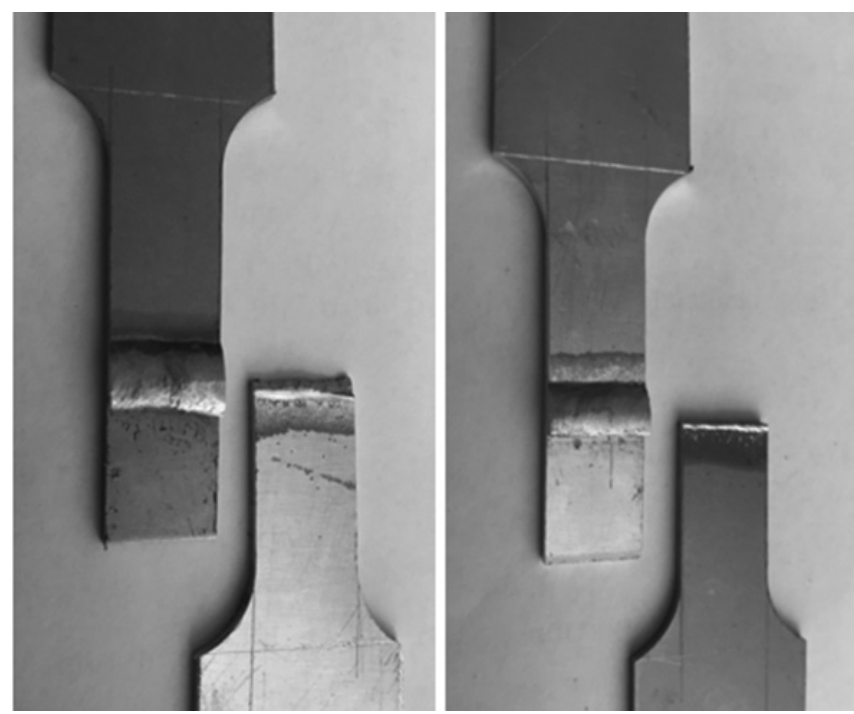

Rys. 7. Przykładowe przełomy złączy lutospawanych po próbie ścinania: w SWC stopu aluminium 5754 (a) i oderwanie lutospoiny od powierzchni czołowej tytanu Grade 2 (b)

Fig. 7. Exemplary fractures of weldbrazed joins after shear test: fracture in aluminum 5754 alloy HAZ (a) and detachment of braze from the face of Grade 2 titanium (b)

\section{Wnioski}

Zastosowanie niskoenergetycznej metody CMT do lutospawania tytanu Grade 2 ze stopem aluminium 5754 umożliwia uzyskanie złączy o dobrej jakości, wysokiej estetyce wykonania i bez rozprysków. Właściwy dobór parametrów procesu oraz sposób ustawienia końcówki uchwytu spawalniczego pozwala uniknąć nadtopienia krawędzi tytanu Grade 2 niezależnie od konfiguracji złącza, co zapobiega utworzeniu się kruchych faz międzymetalicznych na granicy połączenia z lutospoiną. Lutospoina charakteryzuje się płaskim i równomiernym licem ze śladową ilością niezgodności wewnętrznych w postaci porów gazowych, spowodowanych dużym powinowactwem spoiwa Al-Si do tlenu. W konfiguracji, w której stop aluminium 5754 ułożony jest na dole złącza zakładkowego dochodzi do jego przetopienia na całej grubości blachy i wymieszaniu z metalem stopiwa. Powoduje to wzrost twardości w lutospoinie o ok. 15 HV0,05 w porównaniu do twardości lutospoiny utworzonej w odwrotnej konfiguracji złącza, w której występuje jedynie nieznaczne nadtopienie górnej krawędzi blachy

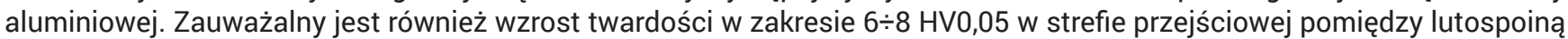
a stopem aluminium 5754. Konfiguracja złącza ma również kluczowy wpływ na wytrzymałość mechaniczną złączy lutospawanych, która w przypadku ułożenia tytanu na dole złącza odpowiada wytrzymałości materiału rodzimego - stopu aluminium 5754 i wynosi 184,8 MPa. Zmiana ułożenia materiałów względem siebie (tytan na górze złącza) powoduje ponad 3-krotne zmniejszenia wytrzymałości złączy na skutek zmniejszenia czynnej powierzchni połączenia. 


\section{Literatura}

[1] Winiowski A., Majewski D.: Brazing of titanium with aluminum alloys, Archives of Metallurgy and Materials, Vol. 62, No. 2, 2013, pp. 763-770.

[2] Li Y.J., Wang J., Liu P.: Weld of dissimilar metals and their applications in industries, Chemical Industry Press, Beijing 2003.

[3] Cao R., Sun J.H., Chen J.H.: Mechanisms of joining aluminum A6061-T6 and titanium Ti-6Al-4V alloys by cold metal transfer technology, Science and Technology of Welding and Joining, Vol. 18, No 5, 2013, pp. 424-433.

[4] Wilden J., Bergman P.: Manufacturing of titanium/aluminum and titanium/steel joints by mean of diffusion welding, Welding and Cutting Vol. 3, 5/2004, pp. 285-290.

[5] Moller F., Grden M., Thomy C., Vollersten F.: Combined laser beam weIding and brazing process for aluminum titanium hybrid structures, Physics Procedia 12/2011, pp. 215-253.

[6] Pfeifer T., Stano S.: Nowoczesne metody lutospawania w aspekcie jakości i właściwości połączeń, Przegląd Spawalnictwa, nr 9/2016, s. 95-102.

[7] Wojdat T., Kustroń P., Lange A., Łącka I.: Badanie właściwości złączy lutospawanych aluminium ze stalą wykonanych przy użyciu spoiw na bazie Al i Zn, Przegląd Spawalnictwa, nr 7/2017, s. 22-25.

[8] Gawrysiuk W.: Technologia lutospawania łukowego. Zalecenia technologiczne i przemysłowe przykłady zastosowań, Biuletyn Instytutu Spawalnictwa, vol. 49 (3), 2005, s. 35-40.
[9] Klimpel A., Czupryński A., Górka J.: Lutospawanie metodą GMA cienkich blach ocynkowanych, Przegląd Spawalnictwa, nr 8-9/2004, s.81-85.

[10] Wojdat T., Kustroń P., Skuratowicz F., Michalak P., Piotrowska P.: Zastosowanie niskoenergetycznego procesu CMT do lutospawania złączy miedź - stal kwasoodporna w różnych osłonach gazowych, Przegląd Spawalnictwa, $\mathrm{nr} 1 / 2018$.

[11] Matusiak J., Czworonóg B.: Niskoenergetyczne procesy spawania łukowego w osłonie gazów do łączenia cienkich blach stalowych, Hutnik - Wiadomości Hutnicze, nr 1/2008, s. 10-16.

[12] PN-EN 573-3:2014-02 Aluminium i stopy aluminium - Skład chemiczny i rodzaje wyrobów przerobionych plastycznie - Część 3: Skład chemiczny i rodzaje wyrobów.

[13] ASTM B265 - 15 Standard Specification for Titanium and Titanium Alloy Strip, Sheet, and Plate.

[14] PN-EN ISO 18273:2016-02 Materiały dodatkowe do spawania - Druty elektrodowe, druty i pręty do spawania aluminium i stopów aluminium - Klasyfikacja.

[15] PN-EN ISO 17637:2017-02 Badania nieniszczące złączy spawanych - Badania wizualne złączy spawanych.

[16] PN-EN ISO 4136:2013 Badania niszczące złączy spawanych metali - Próba rozciągania próbek poprzecznych. 